ARTÍCULO

\title{
CHIVOS EXPIATORIOS DE LA RECESIÓN DE 1953 \\ PANADEROS ESPAÑOLES Y TRABAJADORES AGRÍCOLAS MIGRANTES
}

\author{
SCAPEGOAT OF THE 1953 RECESSION \\ SPANISH BAKERS AND MIGRATORY FARMWORKERS
}

\author{
Catherine VÉZINA \\ Centro de Investigación y Docencia Económicas \\ catherine.vezina@cide.edu
}

\begin{abstract}
Resumen
Los primeros meses de la presidencia de Adolfo Ruiz Cortines (1952-1958) fueron cruciales para consolidar una nueva imagen de la administración federal priista y terminar con la idea de un gobierno corrupto y despilfarrador. La campaña contra el encarecimiento de la vida se combinó pronto con una campaña de moralidad pública que fomentó un discurso nacionalista excluyente. Este artículo se interesa en la relación entre la situación económica y política adversa y la promoción de un discurso patriótico basado en la búsqueda de chivos expiatorios. A través de la prensa capitalina y de regiones preocupadas por la emigración, se observan en lo particular los casos de los panaderos españoles, vistos como responsables del encarecimiento del pan, y de los trabajadores migrantes, antipatrióticos por haber abandonado al campo mexicano.
\end{abstract}

Palabras clave: panaderos, braceros, moral pública, austeridad, prensa, 1953, Adolfo Ruiz Cortines.

Abstract

The first months of Adolfo Ruiz Cortines presidency (1952-1958) were critical for coining a new image of the ruling party, PRI, and effacing the image of a corrupt and wasteful government. A government-sponsored campaign against the rise of the cost of living was reinforced by a public morality crusade that resulted in a nationalist and excluding discourse. This article explores the relation between a muddled economic and political situation and the dissemination of a patriotic discourse targeting scapegoats. An examination of national and regional newspapers allows us to identify the cases of Spanish-origin bakers, who were considered as responsible for the rise of bread price, and migratory workers, who were signaled as unpatriotic for leaving the Mexican fields.

Keywords: bakers, braceros, public morality, austerity, press, 1953, Adolfo Ruiz Cortines.

Información del artículo

Recibido: 4 de julio de 2019.

Aceptado: 25 de septiembre de 2019.

DOI: 10.22201/iih.24485004e.2019.58.70195 
Cuando Adolfo Ruiz Cortines asume el mando del gobierno el 1o. de diciembre de 1952, llama a todo México a unirse para hacer frente a los males que afectan a la sociedad entera. Llama a la nación para intervenir en una "batalla decisiva para hacer llegar al pueblo menesteroso, que es la mayoría de los ciudadanos, lo más indispensable" y para "la revigorización del sentido de nacionalidad". ¿Qué es lo que debe combatir el pueblo mexicano al momento de aquella transición política? Las divisiones en el seno de la familia revolucionaria, el encarecimiento de la vida, la inmoralidad y la corrupción heredados del gobierno saliente. Así, desde el principio del cambio gubernamental, las estrategias económicas, políticas y discursivas implementadas por el nuevo presidente se definen en relación con el legado de la administración anterior: "La clase política se había dividido en dos bandos: uno conformado por los alemanistas y otro por los cardenistas. [...] El país, sobre todo en los últimos meses de esa administración, se había convertido en un verdadero botín dejando las arcas nacionales casi vacías. Hereda, además, un país cuya economía había perdido casi por completo su dinamismo". ${ }^{2}$

Los primeros meses de la administración ruizcortinista fueron cruciales para consolidar una nueva imagen de la presidencia y de la administración federal priista, para terminar con la idea de un gobierno corrupto, despilfarrador y pecador, y para promover un discurso nacionalista que acabaría con las divisiones internas. La campaña contra el encarecimiento de la vida fue el primer proyecto presentado por el nuevo presidente, una prioridad que muy pronto se combinó con medidas moralistas destinadas a sanear los hábitos en el país y con acciones destinadas a fomentar el nacionalismo identitario, principalmente en el Distrito Federal. Olga Pellicer de Brody y José Luis Reyna señalaron bien cómo las reformas a los artículos 34 y 115 constitucionales que otorgaban a la mujer el derecho a votar, la Ley de Responsabilidades de los funcionarios públicos y la Ley Reglamentaria del artículo 28 constitucional en materia de monopolios contribuyeron a construir una nueva imagen de la presidencia y alejarla de los estigmas de la administración de Miguel Alemán. ${ }^{3}$ Este periodo de la

1 "Ruiz Cortines tomó ayer el mando y ofreció pan y bienestar", El Universal, 2 de febrero de 1952, p. 1.

${ }^{2}$ José Luis Reyna y Raúl Trejo Delarbre, La clase obrera en la historia de México. De Adolfo Ruiz Cortines a Adolfo López Mateos (1952-1964), México, Siglo XXI/Universidad Nacional Autónoma de México, Instituto de Investigaciones Sociales, 1996, p. 40.

${ }^{3}$ Olga Pellicer de Brody y José Luis Reyna, Historia de la Revolución Mexicana, 1952-1960. El afianzamiento de la estabilidad política, México, El Colegio de México, 2000, p. 17-20. 
historia reciente mexicana ha sido muy poco estudiado; ${ }^{4}$ parece haber pasado a la historia como una época de estabilidad, consenso y preparación del llamado milagro mexicano. Sin embargo, este momento de transición revela mucho de la negociación que se realizaba dentro de la clase política priista, de las fracturas dentro del grupo en el poder y de las estrategias adoptadas para renovar la imagen del gobierno posrevolucionario y mantener su popularidad.

La búsqueda de chivos expiatorios se encuentra en el centro de estas estrategias para restablecer la legitimidad del gobierno priista de Ruiz Cortines. Escoger cuidadosamente a quiénes culpar de los males sociales y económicos permitía al nuevo presidente matar muchos pájaros de un tiro: rebasar a los críticos del PRI de Miguel Alemán al encabezar la protesta, fomentar un nacionalismo compatible con la campaña de moralidad pública, a la vez que desviaría la atención de los efectos dañinos de las políticas de austeridad económica. Estas respuestas de corte ideológico a una situación económica complicada fomentaron un discurso de odio hacia ciertos sujetos cuya participación en el cuerpo nacional se vio cuestionada.

Los pocos estudios existentes sobre este primer año del gobierno ruizcortinista y que han tratado de este tema se han centrado sobre todo en la Ley de Responsabilidad de los funcionarios públicos (que no parece haber sido aplicada, pero que fue una estrategia discursiva eficaz para sanear la imagen del gobierno) y de la campaña en contra de los monopolios y acaparadores. ${ }^{5}$ Ningún estudio se interesó por la figura de los extranjeros, ni por los emigrantes mexicanos, que también fueron usados como chivos expiatorios durante estos meses de reformulación del patriotismo mexicano. En este contexto, ciertas voces empezaron efectivamente a manifestarse en contra de algunos sujetos antipatrióticos. Por lo tanto, este artículo se interesa por la persistencia de ciertos prejuicios y estereotipos atribuidos históricamente a los españoles en México y a la aparición y transformación de las representaciones del bracero. El objetivo es ver cómo estos estereotipos aparecen en el discurso público en momentos de recesión económica

${ }^{4}$ Un trabajo interesante es el de María del Carmen Pardo, La modernización administrativa en México. Propuesta para explicar los cambios en la estructura pública, 1940-1990, México, Instituto Nacional de Administración Pública/El Colegio de México, 1991, p. 61-80.

${ }^{5}$ Pellicer de Brody y Reyna, Historia de la Revolución Mexicana..., p. 17-20; Sara Minerva Luna Elizarrarás, "Enriquecimiento y legitimidad presidencial. Discusión sobre identidades masculinas durante la campaña moralizadora de Adolfo Ruiz Cortines”, Historia Mexicana, v. 63 , n. 3, 2014, p. 1377-1420. 
y de transición política. No pretendo en este artículo demostrar que la hispanofobia estaba generalizada en la sociedad mexicana de aquella época, pero sugiero que los ataques a los españoles, y a los braceros, eran parte de una estrategia discursiva destinada a generar solidaridad con las acciones del gobierno ruizcortinista durante la recesión de 1953. Como lo veremos más adelante, la hispanofobia ha conocido algunas transformaciones y variaciones de intensidad a lo largo de la vida independiente de México; Tomás Pérez Vejo lo relaciona con el proceso de construcción nacional y de legitimación del poder. ${ }^{6}$ En cuanto a los braceros, y a los trabajadores emigrantes mexicanos en general, han sido culpados en varios momentos de ser traidores y no participar en el desarrollo económico nacional. ${ }^{7}$ En el caso que nos ocupa, estos estereotipos instrumentalizados por el gobierno fueron publicados en la prensa y dio como resultado hacer responsables a dos sujetos históricamente polémicos de los problemas económicos y de los efectos negativos de la política de austeridad.

Para tal efecto, se han revisado las portadas y editoriales de tres periódicos capitalinos y dos regionales. Se han escogido estos rotativos porque ilustran realidades distintas. Por un lado, a través de los periódicos capitalinos se puede entrever la percepción negativa del panadero español que impone precios altos al pan (bolillo y telera, sobre todo), un producto entonces considerado como central en la dieta de los mexicanos de la ciudad de México. ${ }^{8}$ Por otro lado, los periódicos de dos ciudades, Guadalajara y

${ }^{6}$ Tomás Pérez Vejo, "La difícil herencia: hispanofobia e hispanofilia en el proceso de construcción nacional mexicano”, en Manuel Suárez Cortina y Tomás Pérez Vejo (coords.), Los caminos de la ciudadanía. México y España en perspectiva comparada, Madrid, Biblioteca Nueva/Universidad de Cantabria, PUbli-Can, 2010, p. 219-230.

${ }^{7}$ Para más detalles respecto de esta variación de la imagen del bracero, véase Catherine Vézina, “El bracero, ¿héroe o paria? Su representación mediática, 1942-1964”, Signos Históricos, v. XXI, n. 42, julio-diciembre de 2018, p. 180-221.

${ }^{8}$ Los diarios capitalinos fueron seleccionados porque representan distintas posturas ideológicas y se dirigen a distintos públicos. El Popular es un periódico creado en 1938 bajo la dirección de Vicente Lombardo Toledano y que se destina principalmente, pero no exclusivamente, a los miembros de la стм; cuando las relaciones entre Lombardo y la стм se cortan en 1947, este periódico se mantiene activo, pero su tiraje se limita a aproximadamente 10000 copias. El Universal y Excélsior representan por su parte una línea editorial moderada, pero conservadora (Arno Burkholder de la Rosa, La red de los espejos. Una historia del diario Excélsior, 1916-1976, México, Fondo de Cultura Económica, 2016, p. 1268). La mayor parte de sus colaboradores eran universitarios y de clase media de ideología más de derecha; Benjamin T. Smith observa incluso un catolicismo hispanófilo en las contribuciones de ciertos periodistas y editorialistas (Benjamin T. Smith, The Mexican Press and Civil Society, 19401976, Chapel Hill, University of North Carolina Press, 2018, p. 49). Estos dos periódicos 
León, de donde provienen muchos de los migrantes que se dirigen a Estados Unidos dan cuenta de cómo se articulaba el discurso tendiente a culparlos por la escasez de productos básicos. ${ }^{9}$ Aunque la prensa de la época no era necesariamente el vínculo directo del discurso ruizcortinista, reproducía varios elementos de la estrategia discursiva nacionalista que gozaban de buena aceptación pública y que preocupaban a su audiencia.

La escasez y el encarecimiento de los alimentos básicos, tanto en la ciudad de México como en otras regiones, son dos de los puntos de conexión entre estos dos chivos expiatorios. Ambos personajes son centrales para la alimentación del pueblo mexicano; uno por su labor en el campo, el otro porque produce un bien que, ya para esta época, está considerado como central en el consumo cotidiano de los capitalinos. ${ }^{10}$ En 1955, Ignacio García Téllez observaba que "la corriente de trabajadores migratorios se abastece principalmente de las masas rurales [y que] un aspecto panorámico de las condiciones del campo explica los factores que presionan a éxodo de braceros agrícolas". ${ }^{11}$ Esta procedencia rural del migrante sustentó el estereotipo del bracero antipatriótico que abandona la producción de alimentos nacionales en beneficio de la producción agrícola estadounidense. En cuanto a la importancia del pan de trigo, para 1950 se estima que 90\% de la población de la

difieren en el nivel de difusión: el primero no imprimía más de 75000 ejemplares diarios, mientras que Excélsior contaba con un tiraje de más de 121000 y se distribuía hasta algunas ciudades fuera de la capital (Smith, The Mexican Press..., p. 27).

${ }^{9}$ Estos periódicos son El Informador, de Guadalajara (Jalisco), y El Sol de León (León, Guanajuato). Ambos diarios muestran una postura conservadora; el primero siendo propiedad de una familia de la región y el segundo siendo parte de la cadena desarrollada por el empresario anticomunista José García Velasco. Smith, The Mexican Press..., p. 34; Ana María Serna Rodríguez, "Prensa y sociedad en las décadas revolucionarias (1910-1940)", Secuencia, n. 26, 2014, p. 140.

${ }^{10}$ Sandra Aguilar Rodríguez señala que el discurso que "enfatizaba las virtudes del trigo sobre el maíz, heredado de la colonización española, ganó fuerza en el siglo XIX”, fortalecido por ideas darwinistas; esta relación entre el pan de trigo y la modernidad se observó también durante la época posrevolucionaria: "La preferencia por el pan de trigo revela el desdén de la élite gobernante por la dieta de los campesinos e indígenas, además de su interés por imitar la alimentación de los europeos y estadounidenses. Como resultado, el pan de trigo se mantuvo dentro de la canasta básica de alimentos subsidiados por el estado y como alimento base de los desayunos escolares, junto con la leche”. Sandra Aguilar Rodríguez, "La mesa está servida: comida y vida cotidiana en el México de mediados del siglo xx", Revista de Historia Iberoamericana, v. 2, n. 2, 2009, p. 72.

${ }^{11}$ Jorge Durand, Braceros. Las miradas mexicana y estadounidense: Antología (1945-1964), México, Senado de la República/Universidad Autónoma de Zacatecas/Miguel Ángel Porrúa, 2007, p. 327. 
ciudad de México comía pan, principalmente bolillos y teleras. En 1960, el pan de caja (tipo Bimbo) representaba solamente $4 \%$ del gasto total en pan de los capitalinos y los principales consumidores de este producto eran de clase alta. En suma, el bolillo y la telera ya formaban parte de la rutina alimenticia básica de gran parte de la población urbana mexicana a partir de la segunda mitad del siglo xx; cuando los precios de estos productos tienden a subir en 1953, no resulta sorprendente que se desate una campaña de denuncia de los panaderos españoles en los periódicos capitalinos.

Este artículo propone realizar un análisis de la estrategia utilizada para transformar a estos ciudadanos "incompletos" en chivos expiatorios. La prensa permite entrever esta construcción discursiva. ${ }^{12}$ Me interesa ver cómo una situación económica y política adversa fomenta un discurso nacionalista que tiende a excluir a ciertos ciudadanos por presentar, supuestamente, lealtades encontradas. Al considerar el carácter fundamentalmente distinto de los dos sujetos - uno burgués y el otro campesino pobre-podría resultar sorprendente que ambos hayan terminado siendo el objeto de una campaña moralista que presentó a ambos como antipatrióticos. Sin embargo, la transición entre el gobierno de Miguel Alemán y el de Adolfo Ruiz Cortines favoreció la aparición de un discurso moralista que pretendía dejar muy claro la ruptura que existía entre ambos gobernantes; entre la corrupción alemanista y la rectitud ruizcortinista; entre la xenofilia del presidente Alemán y el nacionalismo revolucionario del nuevo presidente veracruzano.

\section{Contexto económico y político}

El llamado para la unidad nacional que se da a principios del año de 1953 debe entenderse en relación con la situación en la cual se retira la administración anterior, la de Miguel Alemán Valdés. Este cambio requerido se debe en buena medida al hecho de que el gobierno de Miguel Alemán no solamente fomentó el crecimiento económico de México basado en un ciclo inflacionista-devaluación, sino también la prosperidad personal de la red de

${ }^{12}$ Vale la pena especificar que el objetivo del presente análisis no es juzgar si estos sujetos migrantes merecían las acusaciones que recibieron en los periódicos de la época; más bien, se trata de explicar estos discursos hispanófobos y antibraceros a la luz de un contexto específico. Tampoco es un intento por verificar la exactitud o la aplicación de las amenazas proferidas en las páginas de los diarios. 
contactos del señor presidente. El clientelismo rampante, la ligereza de la moralidad del presidente Alemán, ${ }^{13}$ así como su xenofilia participaron en la pérdida de confianza del pueblo mexicano en este dirigente priista al terminar el sexenio. Tampoco se podía ignorar la relación amistosa entre Alemán y varios círculos diplomáticos, comerciales y masónicos estadounidenses. ${ }^{14}$

Por otro lado, los últimos meses de su gobierno dejaron entrever claramente los resultados de la estrategia puesta en marcha para marginalizar a los actores indomados del PRI, principalmente la izquierda del partido. La contienda electoral agitada de 1952, que opuso el candidato priista al general Miguel Henríquez Guzmán, revelaba la fractura en el seno de la familia priista. El control autoritario del gobierno alemanista sobre los sindicatos y el ala izquierda del PRI, sus reformas constitucionales que iban en contra del espíritu de la reforma agraria y su exclusividad sobre los puestos públicos políticos no habían dejado satisfechas a todas las facciones del partido revolucionario. ${ }^{15}$ Este momento de ruptura dentro de la élite priista hacía urgente la necesidad de restablecer la legitimidad del presidente de la República, renovar la imagen del partido y reunir las facciones políticas alrededor de objetivos comunes. Así, al momento de iniciar su mandato, Ruiz Cortines quiso restablecer la legitimidad y la nobleza del ejecutivo mexicano y restablecer un discurso patriótico basado en los valores y la moralidad mexicanos. En diciembre de 1952, emprendió entonces una campaña destinada a promover una imagen recta y honesta de su gobierno.

Para distanciarse de las prácticas alemanistas, el nuevo presidente lanzó señales claras durante su discurso inaugural: "Señalando repetida y admonitoriamente a Alemán con el dedo, empleó palabras graves: 'No permitiré

${ }^{13}$ Las historias de amor entre el presidente Alemán y actrices mexicanas y gringas, así como las afinidades entre miembros de su gabinete y la "cosa nostra" no habían pasado desapercibidas. Para más detalles, véase Juan Alberto Cedillo, La cosa nostra en México (19381950). Los negocios de Lucky Luciano y la mujer que corrompió al gobierno mexicano, México, Grijalbo, 2011.

${ }^{14}$ Estas relaciones entre el presidente Alemán y gente de confianza (como el líder del Senado, el coronel Carlos I. Serrano) y círculos diplomáticos y comerciales californianos y estadounidenses han sido documentadas de manera transversal en el libro de Catherine Vézina, Diplomacia migratoria. Una historia transnacional del Programa Bracero, 1947-1952, México, Secretaría de Relaciones Exteriores/Centro de Investigación y Docencia Económicas, 2017. En cuanto a su relación con sus contrapartes masónicas fuera de México, la logia masónica judía Bene-Berith declaró a Miguel Alemán "Hombre del año 1951", Archivo General de la Nación, Fondo Miguel Alemán Valdés, 009/11261.

${ }^{15}$ Elisa Servín, "El movimiento henriquista y la reivindicación de la Revolución Mexicana”, Desacatos, n. 1, 1999. 
que se quebranten los principios revolucionarios ni las leyes que nos rigen [...] seré inflexible con los servidores públicos que se aparten de la honradez y de la decencia". ${ }^{16}$ En las primeras semanas de su administración, Ruiz Cortines siguió con esta estrategia de moralidad pública al presentar una lista detallada de sus bienes y del valor de su patrimonio, exigiendo a todo empleado de la función pública que haga lo mismo, de acuerdo con la nueva Ley de Responsabilidad de los funcionarios públicos. Para fortalecer la legitimidad del gobierno priista, se aseguró la lealtad de los gobernadores al sustituir a los alemanistas por candidatos de su elección y puso mucha atención en la revigorización del sentimiento patriótico mediante programas radiofónicos como la Hora Nacional y celebrando monumentos e instituciones simbólicos de la patria. ${ }^{17}$

En términos económicos, el ideal del nuevo presidente no se distanció del programa de industrialización y modernización del gobierno alemanista. Veía más bien la necesidad de consolidarlo, y sobre todo de estabilizarlo. Los años que van de 1946 a 1955 presentan un crecimiento con un ciclo de devaluación-inflación. En dos ocasiones se devalúa el peso (1948-1949 y 1954), provocando cierta inestabilidad de los precios e inflación. Son años difíciles para la población que tiene que soportar una tasa inflacionaria promedio de $9.3 \%$ anual. ${ }^{18}$ La Segunda Guerra Mundial había provocado un superávit comercial que desaparece una vez terminado el conflicto; la guerra de Corea (1950-1953) reproduce esta situación. La inflación, como había sucedido durante la Segunda Guerra Mundial, crece a partir de julio de 1950. El auge externo, provocado por la guerra de Corea, benefició a la economía en el corto plazo, pero empeoró el problema de la balanza comercial a largo plazo:

[...] el auge externo estimuló la economía interna por lo que el ingreso nacional creció muy rápidamente. [...] Naturalmente, el gasto en importaciones aumentó también dramáticamente, $48.9 \%$ sólo en 1951, lo que ya para ese año generó un déficit en la cuenta corriente de la balanza de pagos de 165.5 millones de dólares, no obstante, la gran contribución de la exportación de servicios que la economía

${ }^{16}$ Enrique Krauze, La presidencia imperial. De Manuel Ávila Camacho a Carlos Salinas de Gortari, México, Tusquets Editores, 1997. Versión Kindle, p. 3643/12152.

${ }^{17}$ Enrique Krauze, Mexico: Biography of Power. A History of Modern Mexico, 1810-1996, New York, HarperCollins, 1997, p. 609-612.

18 Juan Carlos Moreno-Brid y Jaime Ros Bosch, Desarrollo y crecimiento en la economía mexicana. Una perspectiva histórica, México, Fondo de Cultura Económica, 2009, p. 141-147. 
ya realizaba para entonces [...]. Dicho de otra forma, el auge externo que permitió crecer a la economía también la hizo adquirir grandes cantidades de mercancías y servicios en el exterior; cuando el flujo de divisas se interrumpió por la caída de la demanda externa y las exportaciones ni pudieron seguir creciendo, las transacciones con el exterior se volvieron más deficitarias hasta que ya no se pudo soportar más y el tipo de cambio fue devaluado nuevamente. ${ }^{19}$

A partir de 1953, el poder de compra de las exportaciones se reduce de más de $7 \%$ mientras que el PIB creció de $0.3 \%$ respecto del año anterior. Además, la política económica de austeridad seguida por el gobierno de Ruiz Cortines desde sus inicios y hasta finales del año 1953, enfocada en limitar la inflación, provocó un debilitamiento de las inversiones públicas y la suspensión de grandes proyectos, con los consecuentes efectos depresivos sobre la demanda. La atmósfera de incertidumbre que se creó propició a los inversionistas privados a mantener una actitud cautelosa, lo cual agudizó la desaceleración económica. La economía mexicana entró entonces en un marasmo que solamente se iba a solucionar con un cambio de política económica y con la devaluación abrupta, hasta exagerada, de abril de 1954.

Los efectos de esta inestabilidad inflacionista se hicieron sentir entre la población urbana de manera tajante. El precio de varios productos de consumo básico, como el maíz y el trigo, experimentaba un aumento que no parecía tener remedio; a esto, la penuria de alimentos como la carne en el año de 1953 provocó su carestía y engendró un descontento que se manifestó en varias ciudades del centro del país y en la prensa nacional (véase la figura 1).

La baja producción de alimentos de los años anteriores era una de las causas del alza de los precios y resultaba indispensable que aumentara la producción de granos y productos básicos para contrarrestar las tendencias inflacionarias, empeoradas por los acaparadores y especuladores. ${ }^{20}$ En las primeras semanas de la administración ruizcortinista, la estrategia elaborada para abaratar los alimentos se enfocó, por un lado, en la acción de la CEIMSA para asegurar el aprovisionamiento a bajo costo del maíz y el frijol, un plan dirigido a elevar temporalmente la producción de maíz, frijol y

${ }^{19}$ Enrique Cárdenas, La política económica en México, 1950-1994, México, Fondo de Cultura Económica, 2012, p. 44.

${ }^{20}$ Olga Pellicer de Brody y Esteban L. Mancilla, El entendimiento con los Estados Unidos y la gestación del desarrollo estabilizador, México, El Colegio de México, 1978, p. 121. 


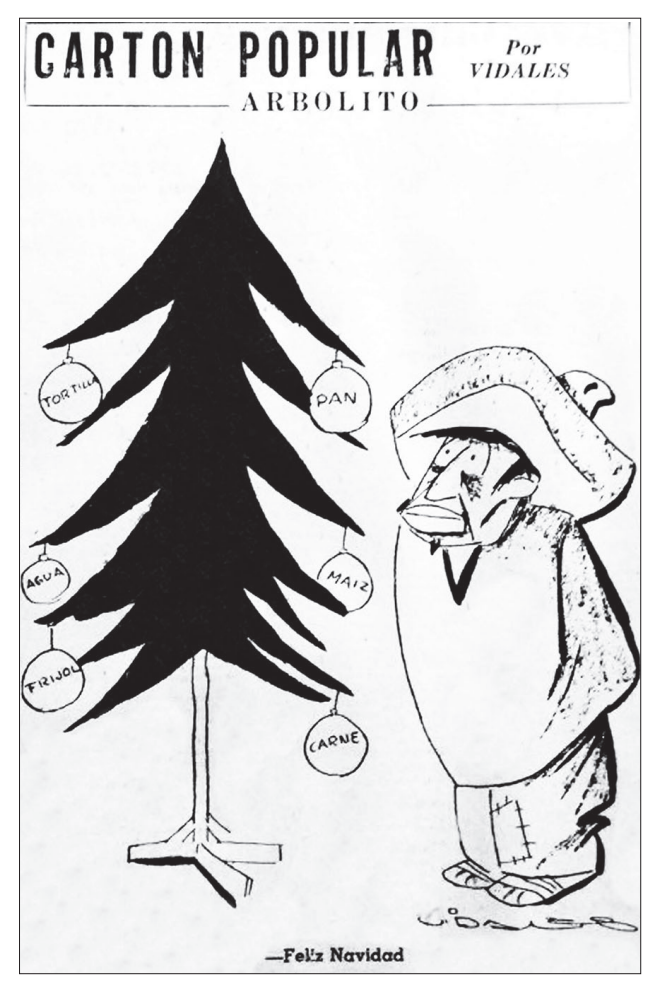

Figura 1. Vidales, “Arbolito”, El Popular, 10 de diciembre de 1953

trigo, y por otro, en la lucha contra los acaparadores y monopolistas. ${ }^{21}$ Estos planes dieron resultados limitados, pues los recortes presupuestales y la tenacidad de los acaparadores sabotearon los esfuerzos para estimular la producción agrícola:

La política estabilizadora, basada en una restricción del gasto público, llevó a limitar las partidas destinadas a promover la agricultura y la ganadería, y las inversiones en obras de irrigación fueron las más afectadas. [...] En términos generales, puede señalarse que los esfuerzos del gobierno para abatir la escasez de alimentos obtuvieron un éxito parcial puesto que se elevó la producción de maíz, trigo y frijol, aunque no en la medida de las necesidades de la población. Por otra parte, el aumento en las cosechas benefició muy poco a la gran mayoría de pequeños agricultores $\left[\ldots . .{ }^{22}\right.$

${ }^{21}$ Pellicer de Brody y Mancilla, El entendimiento con los Estados Unidos..., p. 123-124.

22 Pellicer de Brody y Mancilla, El entendimiento con los Estados Unidos..., p. 128-129. 
De estas medidas, la que realmente rindió frutos, aunque sin eliminar completamente el problema, fue la lucha contra los acaparadores y monopolistas. Para tal efecto, se reformó el artículo 28 constitucional con el objetivo de aplicar sanciones severas a las personas que aprovecharan un contexto de desesperación para provocar el encarecimiento de los productos de consumo básico. Además de cumplir con un objetivo económico claro (lucha contra el encarecimiento), esta táctica correspondía también a la campaña de moralidad pública que el nuevo presidente puso en marcha en los primeros meses de 1953:

al menos los dos primeros años de su gobierno se caracterizan por una campaña estridente contra la corrupción en los círculos oficiales - atribuida implícita o explícitamente al gobierno de Alemán- y al tratamiento de la carestía de la vida - tema crucial en la primera mitad de la década- como un fenómeno no sólo económico sino también moral, donde los comerciantes "malos" eran calificados de inmediato como acaparadores, especuladores, hambreadores. ${ }^{23}$

De esta forma, el gobierno priista ruizcortinista hacía frente no solamente al problema económico, sino a los productores y comerciantes oportunistas, aprovechadores, "sin ética ni moral". Enrique Krauze reporta que, en las primeras semanas de este año, el presidente invitó a Antonio Ortiz Mena, entonces director del Seguro Social, para acompañarlo a visitar las panaderías de la capital y verificar el precio y el peso de sus productos. Esta política de supervisión de los precios dio lugar a un aumento decidido del número de sanciones, particularmente en el Distrito Federal donde el número de multas aumentó 51\% en 1953 respecto del año anterior. ${ }^{24}$ Esta vigilancia incrementada de los comercios hizo, entre otras cosas, que se aumentara el peso del pan por el mismo precio. Como veremos, los periódicos de la capital contribuyeron indirectamente a justificar estas medidas de intervención del Estado; denunciar el monopolio extranjero del pan proporcionaba una legitimidad suplementaria a la presencia de los inspectores en las calles de la capital.

${ }^{23}$ Ariel Rodríguez Kuri, "Los años maravillosos”, en Will Fowler (coord.), Los gobernantes mexicanos, México, Fondo de Cultura Económica, 2008, t. II, p. 263-287.

${ }^{24}$ Pellicer de Brody y Mancilla, El entendimiento con los Estados Unidos..., p. 131. 
Los monopolistas: panaderos españoles

El odio al "gachupín" no se ha concretado con la misma intensidad en todas las épocas; ciertas políticas o contextos contribuyeron a la manifestación del antihispanismo. La integración económica de los españoles durante el Porfiriato y su cercanía a la elite política del mismo periodo hicieron que los revolucionarios, que lucharon en contra de este régimen, fueran muy poco simpáticos a la colonia española establecida en México. ${ }^{25}$ Varios autores han señalado cómo la Revolución Mexicana, y el discurso nacionalista excluyente, fomentó la discriminación hacia los inmigrantes, principalmente los chinos, españoles y estadounidenses, a tal punto que varios fueron deportados o que decidieron retornar a su tierra natal. ${ }^{26}$

Los años que nos interesan en esta investigación presentan características que favorecen la reaparición del estereotipo del español "acaparador" y “avaricio”, poco preocupado por la sociedad mexicana en la cual vive. Se utiliza a propósito el término "reaparición". La imagen del gachupín inmoral no es nueva en 1953. Esta presentación negativa del comerciante, y específicamente del panadero español surge y resurge en distintos momentos de la historia mexicana. Antes de observar esta construcción discursiva en 1953, es preciso examinar ciertos antecedentes para que se pueda entender la continuidad y sobrevivencia de estas imágenes.

Por un lado, vale la pena señalar, como lo han hecho varios autores, que la percepción del español en el México independiente ha sido afectada tanto por la hispanofobia como por la hispanofilia. Mientras que la primera corriente ha dado lugar a la imagen del gachupín, la segunda considera al español como el hidalgo, noble.

${ }^{25}$ Alicia Gil Lázaro, "La presencia de españoles en México en el siglo xx. Continuidades y rupturas en una visión panorámica desde el final del Porfiriato hasta los años ochenta, 1910-1980”, en Ernesto Rodríguez Chávez (coord.), Extranjeros en México. Continuidades y aproximaciones, México, Instituto Nacional de Migración/DGE Ediciones, 2010, p. 133.

${ }^{26}$ Pablo Yankelevich, "Hispanofobia y revolución: españoles expulsados de México (1911-1940)", Hispanic American Historical Review, v. 86, n. 1, 2006, p. 29-60; Pablo Yankelevich, "La política de expulsión de españoles indeseables en México (1915-1934)", Revista de Indias, v. 63, n. 228, 2003, p. 495-518; Moisés González Navarro, Los extranjeros en México y los mexicanos en el extranjero, 1821-1970, México, El Colegio de México, 1994, v. III; Moisés González Navarro, "Xenofobia y xenofilia en la Revolución Mexicana”, Historia Mexicana, v. 18 , n. 4, 1969, p. 569-614. 
Valores muy distintos marcaron la definición de cada una de estas imágenes [gachupín e hidalgo] y también fueron distintos los grupos sociales que hicieron uso de ellas. La primera hace referencia por regla general al pequeño comerciante, asociado a valores negativos como el ser usurero, especulador, egoísta, tacaño, racista; mientras que la segunda era la imagen de la hidalguía, la virtud, la rectitud, el enriquecimiento a través del tesón y el esfuerzo, la sabiduría. ${ }^{27}$

La definición que propone Alicia Gil Lázaro del gachupín pone el énfasis en su clase social o características económicas: "usurero, especulador, egoísta, tacaño", ${ }^{28}$ abarrotero, comerciante con negocio propio, avaricioso. ${ }^{29}$ Contrariamente a otros tipos de discriminación hacia los extranjeros en México (chinos, por ejemplo), los españoles no son perseguidos por su carácter racial; hasta en la Ley de Población de 1947 figura la idea de "mejorar la raza”, incorporando a más inmigrantes blancos.

La relación histórica y los mitos nacionales que han acompañado la construcción de la nación, estigmatizaron a cierta categoría de inmigrantes españoles. Además, la "otredad" cobra fuerza con la Revolución, y la Constitución de 1917 enmarcó claramente esta animadversión hacia "lo otro" al restringir considerablemente las actividades de los extranjeros al incluir un artículo que los mantiene bajo la amenaza de la discrecionalidad ejecutiva para deportarlos. Además, como bien lo menciona Alicia Gil Lázaro, la "indeseabilidad adquirió un nuevo tono en el discurso político sobre la inmigración con posterioridad a 1910 [...]. El nuevo proyecto de nación que emergió de la revolución [...] se hizo mucho más indigenista y mestizófilo. Los extranjeros ya no eran necesarios para la construcción discursiva nacional, [...] sino, todo lo contrario, constituían un obstáculo, la negación de la nación por lo que había que protegerse de ellos y fortalecer la nacionalidad mexicana". ${ }^{30}$ Esto no es sino recordar el plan propuesto por Adolfo Ruiz Cortines para "ofrecer pan y bienestar"; en su discurso inaugural,

${ }^{27}$ Alicia Gil Lázaro, "De colonizadores a inmigrantes gachupines. Los discursos sobre los españoles en la esfera pública mexicana (1880-1930)", Revista Latino-Americana de História, v. 6, n. 17, 2017, p. 126.

${ }^{28}$ Gil Lázaro, “De colonizadores a inmigrantes...”, p. 126.

${ }^{29}$ Alicia Gil Lázaro, “¿Hidalgo o gachupín? Imágenes en torno al inmigrante español en el México revolucionario”, en Agustín Sánchez Andrés, Tomás Pérez Vejo y Marco Antonio Landavazo (coords.), Imágenes e imaginarios sobre España en México, siglos XIX y XX, México, Porrúa/Universidad Michoacana de San Nicolás de Hidalgo/Consejo Nacional de Ciencia y Tecnología, 2007, p. 369.

${ }^{30}$ Gil Lázaro, “De colonizadores a inmigrantes...”, p. 124. 
expone las prioridades de su gobierno, entre las cuales figura "la vigorización del sentido de nacionalidad". ${ }^{31}$

Como ya se señaló, esta construcción discursiva tiene algunos fundamentos de carácter histórico al representar al español como el extranjero que viene a explotar a México. Estas representaciones tienen en parte su origen en la idea de que el español es él que tradicionalmente se ha beneficiado del sufrimiento colectivo, desde la época colonial y hasta las recurrentes crisis sociales y económicas que han marcado la historia mexicana.

En situaciones críticas - afirma Ariel Rodríguez- la sospecha de que las cargas de sufrimiento no se reparten equitativamente, y de que existen beneficiarios de las penalidades de la gente, acaban por configurar la "lógica del enemigo identificado" y en la ciudad de México en esos meses aciagos el enemigo que lucró con el sufrimiento colectivo fue, en la visión capitalina, el español. ${ }^{32}$

Esta concepción del gachupín ha llevado en algunos momentos a reacciones discriminatorias, por no decir violentas, por parte del Estado, pero también de la población mexicana. Entre las más conocidas están las expulsiones de españoles durante la década de 1820, pero en un artículo reciente Gil Lázaro menciona también los motines contra los panaderos durante el Porfiriato. Además, la imagen del panadero, predominantemente de origen vasco, que se consolida durante el Porfiriato tiene que ver con esta relación obrero-patronal en la cual el panadero vasco-navarro, aliado de las autoridades porfiristas, se comporta como un explotador, hasta encerrar a sus empleados y negarles un salario fijo: "Los presuntos motores de la modernización capitalista - los funcionarios porfiristas y los empresarios extranjeros- buscaron restringir [el] progreso [de los panaderos de la ciudad de México] a cada paso. ${ }^{33}$ La figura del panadero español cabe dentro de las definiciones que se han dado del gachupín, del avaricioso dispuesto a sacar provecho de un contexto económico adverso, cueste lo que cueste. Esta situación es precisamente la que se reporta en un Estudio sobre el encarecimiento de la vida en México, realizado entre 1914 y 1916

31 "Ruiz Cortines tomó ayer el mando y ofreció pan y bienestar", El Universal, 2 de diciembre de 1952, p. 1.

32 Ariel Rodríguez Kuri, “Desabasto, hambre y respuesta política, 1915”, en Carlos Illades y Ariel Rodríguez Kuri (coords.), Instituciones y ciudad. Ocho estudios históricos sobre la ciudad de México, México, ¡Uníos!, 2000, p. 162-163.

${ }^{33}$ Robert Weis, "Las panaderías en la ciudad de México de Porfirio Díaz: los empresarios vasco-navarros y la movilización obrera”, Revista de Estudios Sociales, n. 29, 2008, p. 80. 
cuando la ciudad de México sufría del desabasto y del encarecimiento de la vida provocados por los conflictos armados en el país. ${ }^{34}$ Gil Lázaro señala que el estudio, rubricado por la alta comandancia constitucionalista, explica que la crisis alimentaria se debe a las actividades monopolísticas de los comerciantes de artículos de primera necesidad - casi todos españoles-. ${ }^{35}$ En las décadas siguientes, ya no se volverá a acusar tan directamente a los panaderos, pues su relación con el estado posrevolucionario cambia significativamente después del conflicto armado.

La relación de los panaderos españoles con el estado posrevolucionario no es de las más sencillas. Después de la Revolución, al parecer los panaderos sirvieron los fines de los gobiernos, asegurando alimentos a la capital del país (1919-1928); esta alianza se concretó a veces con la colaboración de las autoridades para terminar con las huelgas de los trabajadores panaderos. Una vez que el estado posrevolucionario estuvo asentado, y las relaciones laborales mejor reguladas, los panaderos se afianzaron con el Estado y los trabajadores panaderos para hacer frente a los pequeños establecimientos y a los vendedores callejeros de pan, lo que favoreció la consolidación de un casi monopolio de los panaderos españoles (1929-1940):

Unlike the immigrants in Mexico, [...] the Spanish bakery owners were able to form a monopoly that deeply ensconced itself into the daily life of the city and into the dynamics of State formation. The bakery owners first fulfilled their middlemen function when the Postrevolutionary regime relied on them to keep the population fed, an imperative that repeatedly trumped the bakery workers' demands. Second, the State relied on the Spaniards in order to negotiate with organized labor and incorporate workers into a tractable organizational framework that would bolster state authority. ${ }^{36}$

Aunque no hay muchos trabajos históricos que nos permitan obtener un análisis de la relación entre los panaderos y el Estado posrevolucionario

${ }^{34}$ Yankelevich subraya la importancia de los factores económicos, o religiosos, para entender el comportamiento de la sociedad mexicana hacia la colonia española asentada en distintas regiones de México. Los tiempos adversos favorecen una conducta basada en la denuncia de los actos "soberbios" de los españoles. Pablo Yankelevich, "Denuncias e investigaciones contra españoles. Orígenes y desenvolvimiento de una conducta social y una práctica política en el México revolucionario”, en Agustín Sánchez Andrés, Tomás Pérez Vejo y Marco Antonio Landavazo (coord.), Imágenes e imaginarios...

${ }^{35}$ Gil Lázaro, “La presencia de españoles en México...”, p. 161.

${ }^{36}$ Robert Weis, "Immigrant Entrepreneurs, Bread, and Class Negotiation in Postrevolutionary Mexico City”, Mexican Studies, v. 25, n. 1, 2009, p. 76. 
después de la Segunda Guerra Mundial, Weis señala que los panaderos españoles supieron sacar provecho de los subsidios para la harina de trigo para consolidar su hegemonía de la panadería en la ciudad de México. ${ }^{37}$ Lo que se percibe entonces claramente en los periódicos del año que nos ocupa es un ataque frontal por parte de las asociaciones de panaderos mexicanos para denunciar y terminar con las prácticas monopolísticas de los panaderos españoles, dueños de grandes establecimientos.

Para la década de 1950 los extranjeros ni siquiera representan 1\% de toda la población mexicana, ${ }^{38}$ y la "colonia española" ${ }^{39}$ representaba menos de $0.2 \%$ de la población total en México en 1960 (menos de 50000 individuos en todo). Sin embargo, la imagen negativa del comerciante español aparece con fuerza en los periódicos nacionales y regionales en tiempos de malestar económico, como lo es el año de 1953. La situación que se reporta respecto de los españoles es sobre todo la que prevalece en el Distrito Federal, entidad donde se encuentra la mayor parte de la colonia española en México (la gente de nacionalidad española representa $0.67 \%$ de la población del DF en 1960). ${ }^{40}$ Pero la importancia de esta presencia española no se contabiliza en número de personas, sino en sus características económicas:

${ }^{37}$ Robert Weis, Bakers and Basques: A Social History of Bread in Mexico, Albuquerque, University of New Mexico Press, 2012, p. 152.

${ }^{38}$ Para los años que nos interesan, según el Censo de Población de 1960, en 1950 el número de personas nacidas en un país extranjero representaba el $0.7 \%$ de la población total de México. En 1960, de una población total de 34923 129, solamente 223468 personas radicadas en México habían nacido en un país extranjero (0.6\%). Véase Secretaría de Industria y Comercio, Dirección General de Estadísticas, "Población total, por entidad federativa de residencia, sexo y censo, según lugar de nacimiento”, Octavo Censo General de Población, México, Secretaría de Industria y Comercio, Dirección General de Estadística, 1960.

${ }^{39}$ Se refiere a la "colonia española", o sea, a los inmigrantes españoles llegados a América a fines del siglo XIX y principios del Xx. Dolores Pla Brugat precisa que esta colonia española presenta características distintas a los refugiados republicanos que llegarán a México a partir de 1936. El sujeto que estudiamos en este artículo es parte de esta "colonia española” y los prejuicios en su contra son los que sufrieron estos inmigrantes de educación más pobre. Dolores Pla Brugat, "Ser español en México, para bien y para mal", en Delia Salazar Anaya, Xenofobia y xenofilia en la historia de México, siglos XIX y XX, México, Instituto Nacional de Migración/Instituto Nacional de Antropología e Historia/DgE Ediciones, 2006, p. 147.

${ }^{40}$ Secretaría de Industria y Comercio, Dirección General de Estadística, "Población total, por entidad federativa de residencia, sexo y censo, según lugar de nacimiento" y "Población extranjera residente, por entidad federativa de residencia y país de nacimiento, según sexo", Octavo Censo... 
la presencia de estos españoles en México era importante debido a su inserción económica y social. El perfil ocupacional de la colonia era el siguiente: el sector primario -agricultura, ganadería y pesca-incorporaba sólo al 6.67\%; la industria, el comercio y las finanzas, al 43.48\%; 25.92\% eran asalariados ocupados en estas áreas; $5.64 \%$ trabajadores especializados, $2.28 \%$ estaban dedicados a actividades profesionales; por último, un $16.1 \%$ está asociado a trabajos no especializados o no especificados, entre los cuales posiblemente predomine el trabajo doméstico y de servicios. ${ }^{41}$

La posición económicamente favorable que ocupa la "colonia española" en México, y su fama de comerciantes exitosos, la hace vulnerable al recelo de la gente popular, en busca de un chivo expiatorio que culpar por el empeoramiento de su poder adquisitivo. ${ }^{42}$ La lógica de "demonización [del español gachupín] y victimización [del infeliz mexicano]"43 que había llevado la comandancia revolucionaria a culpar a los españoles por la crisis alimentaria de 1914-1916 se pone nuevamente en marcha durante la campaña de lucha contra el encarecimiento en 1953.

Las noticias relativas a la lucha contra los monopolistas y acaparadores aparecen casi diariamente en los periódicos de la capital. Los principales "hambrientadores" que se denuncian son los vendedores de carne, de maíz y de pan. En los primeros días de enero, El Universal publica un artículo sobre "La lucha contra el encarecimiento" en el cual, después de pocas líneas, aparece repentinamente la figura del panadero avaricioso. Sin precisar el origen étnico de los panaderos (que era de por sí bien conocido en la capital del país, por ser un rasgo étnico-económico tan distintivo como los “joyeros judíos"), el artículo menciona que los panaderos se oponen a sujetarse a los precios oficiales porque "se niegan a conformarse con una tasa de lucro inferior a la muy elevada que hasta ahora han obtenido y que

${ }^{41}$ Pla Brugat, "Ser español en México...”, p. 147.

${ }^{42}$ Desafortunadamente, es difícil conocer el número exacto de españoles que se dedicaban a la panadería, por lo cual es imposible conocer qué proporción de esta industria monopolizaban. Clara E. Lida explica que el estudio de la incidencia de los inmigrantes españoles en las actividades económicas del país después de la Revolución es una "asignatura todavía pendiente". Clara E. Lida, "Los españoles en el México independiente: 1821-1950. Un estado de la cuestión”, Historia Mexicana, v. 56, n. 2, 2006, p. 622.

${ }^{43}$ Hace referencia al análisis de Alicia Gil Lázaro del panfleto de Germán List Arzubide de 1924, ¡Mueran los gachupines!, en el cual se percibe un nacionalismo "a la mexicana" terriblemente xenófobo. La autora concluye: "demonización y victimización son complementarios [...]: dominadores y crueles españoles frente a humildes e infelices mexicanos". Gil Lázaro, “De colonizadores a inmigrantes...”, p. 130. 
desean seguir obteniendo". ${ }^{44}$ Además de señalar la avaricia de los panaderos, apuntan del dedo a las "maniobras encarecedoras de los comerciantes detallistas [...] posibles debido [a que] disfrutan de un monopolio parcial". ${ }^{45}$

Unos días más tarde, El Popular, periódico vocero del Partido Popular, ahora satélite del PRI, publica en su portada un artículo sensacionalista titulado "El 33 a los extranjeros voraces". ${ }^{46}$ El mensaje está claro: se debe vigilar de cerca a los extranjeros, acaparadores por excelencia y aplicar sanciones radicales para evitar que vuelvan a burlarse de las leyes nacionales. Es importante precisar que no es una instrucción del gobierno federal, ni de cualquier otra autoridad gubernamental; el periódico informa de una petición realizada por el "Frente Único de Locatarios y Comerciantes en Pequeño del Distrito Federal" al presidente Ruiz Cortines. Sin embargo, si observamos esta postura junto con otras declaraciones que se hacen en este sentido por otras organizaciones de la capital, es posible deducir que no era un discurso que iba en contra de las políticas oficiales; El Popular ya no publicaba artículos que no complacían a las elites del PRI y mantenía un discurso de carácter nacionalista, antiimperialista y con tintes xenófobos.

El 7 de enero El Universal reporta una iniciativa del director de la Penitenciaria del Distrito Federal, apoyada por Ernesto P. Uruchurtu, jefe del Distrito Federal, que tiene como propósito participar en la lucha contra el encarecimiento de la vida. Para ayudar al "presidente Ruiz Cortines en su patriótica labor de combatir los monopolios", el director de la Penitenciaria instituyó un programa de fabricación de pan de "magnífica calidad a precio bajo". ${ }^{47}$ Esta política no va sin recordar que desde la Nueva España y hasta mediados del siglo XIX era común que las cárceles produzcan pan para surtir los hospitales, hospicios y talleres. ${ }^{48} \mathrm{Si}$ El Popular había tomado la precaución de evitar los términos despectivos para hablar de los monopolistas, este periódico no duda en expresar de manera cruda su sentimiento hacia los españoles.

Este pan [...] será destinado a surtir a los expendios de pan de las zonas proletarias de la Capital, así como de las colonias humildes [...].

44 "La lucha contra el encarecimiento", El Universal, 20 de enero de 1953, p. 3.

45 "La lucha contra el encarecimiento", El Universal, 20 de enero de 1953, p. 3.

46 "El 33 a los extranjeros voraces", El Popular, 4 de enero de 1953, p. 1.

47 "Los presos de la Peni principiaron a fabricar pan de magnífica calidad", El Universal, 7 de enero de 1953, p. 7.

48 "El pan en el tiempo", Karsapan, https://karsapan.com.mx/el-pan-en-el-tiempo/ (consultado el 28 de junio 2019). 
Esta fabricación de pan, especialmente de bolillo, constituye de hecho un fuerte golpe al monopolio del pan, que está en manos de un grupo de voraces gachupines, que hasta hace poco venían siendo protegidos por algunos funcionarios. ${ }^{49}$

En estas pocas frases son reunidos los principales ejes discursivos de la política ruizcortinista: lucha contra el encarecimiento a favor de los mexicanos humildes, depuración de los funcionarios corruptos, hispanofobia y revigorización de la nacionalidad. La lucha contra el encarecimiento encuentra entonces en la figura del panadero español, “voraz”, el chivo expiatorio perfecto: la política nacionalista y de moralidad pública ruizcortinista combate a otro históricamente odiado.

La campaña moralizadora y de revigorización de la nacionalidad mexicana no se limita a los panaderos españoles, otros extranjeros están en la mira de las autoridades y de la prensa. Estas campañas para verificar la legalidad de la estancia de los extranjeros en México caben dentro de la retórica moralista, legalista, ambiental. Otros nacionales, como los estadounidenses o los guatemaltecos, o categorías de extranjeros, como los artistas o los que exceden sus visas, ${ }^{50}$ reciben la atención mediática, pero no es posible hablar de una campaña sistemática para acabar con la presencia o las actividades de un sujeto en particular. El carácter único del caso de los panaderos españoles es la visibilidad y la frecuencia con la cual la prensa nacional los menciona en los primeros meses del gobierno ruizcortinista; los ataques a esta comunidad específicamente se repiten constantemente hasta 1954,

49 "Los presos de la Peni principiaron a fabricar pan de magnífica calidad", El Universal, 7 de enero de 1953, p. 7.

${ }^{50}$ A principios del mes de enero reportan a 22 extranjeros detenidos en la cárcel de la Secretaría de Gobernación en espera de ser deportados y dos semanas más tarde se anuncia una campaña destinada a revisar los expedientes de los extranjeros radicados en la república con el objetivo de verificar la calidad migratoria de cada uno, y proceder a la deportación en los casos que no respetan las leyes migratorias del país. "22 extranjeros en la cárcel de la Secretaría de Gobernación, en espera de ser deportados”, Excélsior, 5 de enero de 1953, p. 1; "Probable expulsión de extranjeros”, Excélsior, 19 de enero de 1953, p. 1. Dos meses más tarde, la Secretaría de Gobernación reitera su intención de deportar a los extranjeros, principalmente artistas, que se encuentran ilegalmente en el país. "Deportación de extranjeros que se hallan ilegalmente en el país”, El Popular, 9 de marzo de 1953. En enero, el presidente Ruiz Cortines se compromete a vigilar la entrada de braceros de Guatemala para frenar y regularizar este movimiento. "Dique en Chiapas a braceros de Guatemala”, Excélsior, 21 de enero de 1953, p. 1. En febrero de 1953, denuncian las maniobras de dos estadounidenses que han despojado a familias mexicanas de sus inversiones en casas habitación. "Damandan [sic] justicia dos mil quinientas familias víctimas de voraz extranjera”, El Popular, 2 de febrero de 1953 , p. 1 y 2. 
combinándose con las noticias diarias de lucha contra el encarecimiento. Aunque el gobierno ruizcortinista no encomendó un reporte oficial sobre la crisis alimentaria de 1953, como lo había hecho la comandancia constitucionalista en 1917 , la recurrencia de las alusiones a los panaderos españoles en la lucha contra el encarecimiento sugiere una conclusión similar a la del reporte de 1915: los españoles participan en las maniobras monopolistas.

Además, en la prensa se señala a los panaderos españoles por no respetar las políticas mexicanas ni a los trabajadores mexicanos. En los diarios capitalinos, señalan que estos panaderos extranjeros se benefician de la subvención al trigo concedida por el gobierno federal y que no respetan las instrucciones del gobierno para abaratar el costo del pan. Las asociaciones de panaderos mexicanos reprochan a los panaderos españoles de utilizar esta harina para hacer pasteles de lujo que rinden más beneficios en vez de hornear bolillos y teleras. Los ataques van dirigidos a los monopolistas españoles que no son patriotas; así lo formula la Asociación de Industriales Mexicanos del Distrito Federal en Panificación:

“EL MONOPOLIO DEL PAN SE DESTRUYE EN POCAS hORAS, Y CON ÉL, LA ESCASEZ DE BOLILLO Y CARESTÍA DEL PAN BLANCO EN EL DF, con el solo hecho de retirársele al grupo español los 665000 bultos de harina subsidiada con los que no HACE BOLILLO Y TELERA, y se nos entregue a 500 Industriales Panificadores Mexicanos, que si sentimos las necesidades de la patria, por lo que nos comprometemos a transformar esa harina en bolillo y telera de 40 y 80 gramos [...]. ${ }^{51}$

En otro artículo, precisan que el subsidio del pan, no sólo está mal utilizado, sino que está distribuido de manera injusta, alegando que los panaderos españoles han gozado de un tratamiento privilegiado en los años anteriores. Para sostener este argumento la Asociación de Industriales Mexicanos del DF en Panificación da como ejemplo los 9200 bultos mensuales de harina subsidiada que recibe Pan Roll,,$^{52}$ una empresa orgullosamente cien por ciento mexicana, en comparación con los 30000 bultos mensuales de harina subsidiada que recibe la firma española de Vázquez y Burto (quienes

${ }^{51}$ Las mayúsculas aparecen en el documento original. "El monopolio de la industria del pan debe ser destruido”, El Popular, 14 de enero de 1953, p. 1 y 2.

52 "Nuestra empresa, PanRoll, http://www.panroll.com.mx (consultado el 1 de julio de 2019). 
además producen bizcochos y pasteles) ${ }^{53}$ Esta situación es reportada en varios periódicos de la capital simultáneamente; El Universal agrega a esta noticia que los panaderos españoles han mecanizado su industria para desplazar a los trabajadores mexicanos, algo que los productores mexicanos denuncian como antipatriótico: "Los industriales mexicanos están de acuerdo en la mecanización de la industria; pero sin desplazar a los trabajadores, como aseguran que lo han hecho los panificadores extranjeros". ${ }^{54}$ Las quejas en contra de los panaderos españoles se mantienen vivas a lo largo del año de 1953, cuando la economía tambalea y el costo de la vida sigue alto. En su editorial del 3 de diciembre, El Popular se pronuncia decididamente en contra del monopolio del pan, en manos de extranjeros insolentes:

Negocios de lo más turbio, influencias de los más negro, procedimientos de hampa y hasta complicidad criminal de falsos líderes obreros, han ido formando una verdadera muralla de infamia en torno al monopolio hasta hacerlo casi invencible. [...] tan bien se entendieron en otras épocas con funcionarios venales y desleales. [...] Y, si es cierto que el monopolio del pan puede sufrir - todavía falta que lo sufra - un rudo golpe, también es verdad que las medidas que se anuncian o empiezan a ponerse en práctica, no son suficientes para acabar radicalmente con su fuerza negra y explotadora. Y lo que el pueblo quiere es que una justiciera guillotina, acabe de una vez por todas y para siempre con los monopolios. ${ }^{55}$

Para colmo, este mismo mes acusan a los panaderos de ser envenenadores públicos y reclamar severas sanciones para quienes incurran en sus ilícitas actividades. ${ }^{56}$ Durante el año de 1954, las acusaciones en contra de los españoles desaparecen poco a poco de los periódicos. La cancelación de los subsidios a la harina para los panaderos por parte del gobierno ruizcortinista es sin duda la explicación principal del cambio de tono en la prensa. Además, después de haber devaluado el peso, el presidente mexicano cambia su estrategia económica, pasando de un programa de austeridad que no hizo más que desalentar la economía (y los empleos, y consecuentemente el poder de compra) a uno de gasto público importante y de supervisión de la inflación. Los disturbios económicos de 1953 y 1954

53 "El subsidio del pan está mal distribuido", El Popular, 20 de enero de 1953, p. 1 y 6.

54 "El monopolio del pan y el problema de la carne", El Universal, 14 de enero de 1953, p. 1 y 15 .

55 “El monopolio del pan. Editorial”, El Popular, 3 de diciembre de 1953, p. 3.

56 "Persigue Salubridad a los panaderos que nos envenenan con grasas para automóvil", El Popular, 9 de diciembre de 1953, p. 1 y 2. 
amenazaban con afectar la vida política, la estabilidad priista y las autoridades respondieron estableciendo una nueva política económica que sería el fundamento del desarrollo estabilizador, el "milagro mexicano".

\section{Los desertores: braceros y mojados}

La percepción del bracero no es fija o estática; como el programa bilateral, ${ }^{57}$ esta imagen evoluciona a lo largo de los años. El bracero pasa de héroe nacional, a víctima, y en algunas ocasiones a traidor de la patria. La figura del bracero se adapta al contexto nacional, según si es del interés nacional que se vaya a ayudar a los Estados Unidos, o si por el contrario el acto de cruzar la frontera sea perjudicial para México. Además, en más de una ocasión podemos observar en las corrientes de opinión pública que la migración braceril es vista como una irreconciliable con el proyecto nacionalista modernizador.

A finales de la década de 1940, el bracero perdió el aura de valentía que se le había atribuido en tiempos de la Segunda Guerra Mundial, cuando su sacrificio era visto como un gesto patriota. En pocas ocasiones después de este momento bélico el bracero se vuelve objeto de orgullo nacional. Entre las características más positivas asociadas a este personaje, está la esperan$\mathrm{za}$, que representaba su experiencia internacional, una confianza basada en la "importación" de conocimientos modernos heredados en los campos agrícolas de Estados Unidos y que los braceros iban a difundir en México cuando regresaran. El bracero se iba a convertir en agente de la modernidad. Sin embargo, estas promesas no se concretan y no es la imagen del bracero

${ }^{57}$ Hay que recordar que este "programa" que regula la migración temporal de trabajadores agrícolas mexicanos (sobre todo, aunque hubo un programa para el sector ferroviario de 1943 a 1945) a Estados Unidos es compuesto por una sucesión de acuerdos bilaterales que presentan diferencias significativas. El primer acuerdo fue firmado en agosto de 1942, pero se modificó en 1943, y fue reemplazado en 1947 por otro acuerdo. Entre 1948 y 1951, se acordó otro convenio, cancelado unos meses después y se instauró entonces un entendimiento transitorio entre los dos gobiernos. Finalmente, en 1951 se renegoció el programa de trabajo agrícola temporal y se llegó a un nuevo acuerdo que estuvo vigente, con ciertas modificaciones, hasta 1964. Cuando examinamos los convenios, nos damos cuenta de que México se benefició con más fuerza en ciertas negociaciones (1942, 1943, 1951) y perdió cierto margen en otras, debido a la situación internacional, pero también al contexto económico mexicano más difícil $(1947,1949,1953)$. 
transmitida por la prensa nacional y local. ${ }^{58}$ La fuga de una cantidad significativa de ciudadanos productivos representa una falla del desarrollo industrial, la vergüenza de México. ${ }^{59}$

En este contexto, es posible entender cómo un sujeto que es formalmente ciudadano de México se vuelve considerado como un sujeto incompleto y dual. Un sujeto que rechaza la patria y que causa humillación al cuerpo nacional. El año de 1953 no es el más sencillo ni el más armonioso para la gestión del convenio bilateral sobre los trabajadores agrícolas temporales entre México y Estados Unidos. Desde su llegada al poder, Adolfo Ruiz Cortines había hablado de la cuestión braceril en términos de "problema" que debía encontrar una solución. ${ }^{60}$

En este contexto, en múltiples ocasiones, el mandatario mexicano señala su deseo de disminuir el número de braceros, de frenar este fenómeno migratorio. Al mismo tiempo, en el Congreso de los Estados Unidos, se realizan las discusiones en torno de la extensión de la Ley Pública 78 que regía el programa bilateral desde 1951. Muy temprano en este debate se hizo ver claramente la receptividad muy limitada de las demandas mexicanas por parte de la clase política estadounidense. ${ }^{61}$ Cuando las negociaciones empiezan entre los gobiernos mexicano y estadounidense en septiembre de 1953, queda claro para el lado americano que la administración del programa debía hacerse más compatible con las necesidades de los agricultores y, que si México no se mostraba abierto a aportar ciertos cambios, la

${ }^{58}$ Véase Vézina, "El bracero, ¿héroe o paria?..."

${ }^{59}$ En numerosas ocasiones, el bracero (y el mojado) es tomado como ejemplo del fracaso del proyecto revolucionario. Aunque no culpan al bracero por su pobreza (el gobierno priista es visto como responsable de las faltas de garantías para la gente del campo), los periódicos lo representan como un agente susceptible de provocar motines, de robar o insalubre. Esto se verifica sobre todo en la prensa local de los estados y ciudades donde se encuentran los centros de reclutamiento.

${ }^{60} \mathrm{Su}$ principal propuesta de solución residía en la apertura y colonización de las zonas costeras tropicales y una mayor atención de los puertos mexicanos (programa conocido como la Marcha al Mar). Con esta estrategia, pretendía crear empleos para todos los mexicanos, sin evaluar el costo social de la relocalización de una gran parte de la población establecida en las zonas centrales de México. Además, el presidente Ruiz Cortines enfatizaba la necesidad de dar más protecciones a los braceros en los Estados Unidos; como lo había hecho el gobierno de Miguel Alemán al inicio del conflicto en Corea, Ruiz Cortines pensaba poder sacar provecho de una situación internacional conflictiva para presionar a su socio del norte en conceder ciertas garantías a los trabajadores mexicanos.

${ }^{61}$ Richard B. Craig, The Bracero Program: Interest Groups and Foreign Policy, Austin, University of Texas Press, 1971. Versión Kindle, p. 2070/4983. 
posibilidad de un programa unilateral de reclutamiento de mano de obra mexicana se volvía una eventualidad. ${ }^{62}$

Para resumir la situación, México se encontraba desde el invierno de 1953 en una situación desfavorable para presionar a Estados Unidos y la salida descontrolada de trabajadores mexicanos a ese país daba municiones a los negociadores estadounidenses al demostrar la validez del reclutamiento unilateral. En este momento, el objetivo principal de la administración de Ruiz Cortines respecto de los braceros se vuelve entonces el de desincentivar a los futuros candidatos a salir del país. ${ }^{63}$

Veamos cómo se articula este discurso sobre el bracero con la recesión económica de 1953. El bracero es representado como sujeto antipatriótico en este momento de inestabilidad económica (y diplomática) por tres razones principales: 1) porque al ausentarse del país, no participa en la producción agrícola nacional, empeorando así el problema de la carestía de los alimentos; 2) porque las deportaciones de los mexicanos que han salido clandestinamente o que se quedaron de forma irregular en Estados Unidos cuestan dinero al erario nacional; y 3) porque al salir del país durante los tiempos difíciles de las negociaciones bilaterales provocan una pérdida del poder negociador de México.

Los braceros, al abandonar el país, se convierten, entonces, en uno de los chivos expiatorios. No sólo empañan la imagen del país: como son seleccionados por las autoridades mexicanas y estadounidenses, son considerados como los más aptos físicamente de la nación... pero abandonan a esta patria para ir a ayudar los granjeros americanos. ${ }^{64}$ Esta representación del bracero como traidor a la patria no se limita a la prensa: el principal líder sindical de la época, Fidel Velázquez, los culpa no solamente de abandonar su tierra, sino de "acentuar el grave problema del encarecimiento de los artículos de consumo necesario, sobre todo para la alimentación del pueblo". ${ }^{65}$ ¿La solución propuesta por el sindicalista para limitar el éxodo?: castigar al trabajador

${ }^{62}$ Craig, The Bracero Program..., versión Kindle, p. 2101/4983.

${ }^{63}$ La campaña para desincentivar la salida de los braceros toma un tono antiimperialista. Vézina documentó la narrativa que se establece entre la actitud imperialista de los Estados Unidos en Guatemala a principios de 1954, las negociaciones bilaterales entre México y Estados Unidos y la imagen del bracero que se proyecta en la prensa. Vézina, "El bracero, ¿héroe o paria?...”, p. 207-215.

64 "Mexicans Protest Outflow of Labor", The New York Times, 24 de julio de 1952, p. 24.

65 "Resolución de la Conferencia Internacional de Sindicatos Mexicanos y Estadounidenses convocada por la ORIT", Stanford Library, Ernesto Galarza Papers, folder 3, marzo de 1953. 
con impedirle que sea readmitido en su trabajo y al campesino con perder su título de propiedad si se va de bracero. De aplicarse esta recomendación, la situación del bracero se volvería francamente precaria; arriesgaría su patrimonio en México al salir temporalmente a trabajar en los Estados Unidos. Ningún archivo indica que el gobierno mexicano haya adoptado este tipo de medidas drásticas, pero esta amenaza es reiterada en distintos momentos para desincentivar a los candidatos braceros.

La amonestación a los braceros por encarecer los alimentos básicos se repite a lo largo del año 1953 y principios de 1954. Lo que la prensa nacional y el presidente Ruiz Cortines llama "el problema de los braceros" se debe, por un lado, a la discriminación que sufren en los Estados Unidos, pero también a su improductividad para México. ${ }^{66} \mathrm{~A}$ principios del mes de marzo, antes de empezar masivamente las contrataciones de braceros, $E l$ Sol de León, periódico conservador de uno de los estados de donde sale la mayor cantidad de braceros, publica un editorial en el cual se pinta un retrato antipatriótico de esta emigración:

aparte de las vejaciones y los maltratos de nuestros nacionales, el hecho es grave porque la salida de brazos se refleja en la producción y, por lo tanto, en el costo de la vida. No es posible reducir el precio de las subsistencias, si los mejores brazos emigran de nuestros campos, dejándolos abandonados. [...]

Y es ahora, justamente, cuando más necesitamos de ese esfuerzo que se va del país y de esos hombres. No es verdad que la tierra mexicana sea improductiva, ni es cierto que falte sitio en el país para el trabajo de los braceros. Todo lo contrario. ${ }^{67}$

Por lo que hemos podido documentar, las acusaciones a los braceros por la carestía de la vida y por la improductividad de las tierras no se fundamentan en estudios, datos confiables o en casos concretos. La única región agrícola que sí experimenta una penuria de mano de obra es la de las localidades algodoneras del norte del país, que buscan una fuerza laboral masiva y barata. Las declaraciones que se hacen entonces en la prensa y que señalan a los braceros como participantes del encarecimiento de la vida tienen como objetivo buscar a un culpable; en este caso, el bracero es una presa fácil dado que en repetidas ocasiones se ha cuestionado su valor nacional, su carácter patriótico.

66 "Grave problema constituyen los braceros”, Excélsior, 4 de junio de 1953, p. A-4.

67 “La esclavitud de los braceros”, El Sol de León, 7 de marzo de 1953, p. 2. 
No es insignificante tampoco que, además de enseñar una cara antipatriótica del bracero, estos periódicos quieren presentar a este trabajador migrante como un ciudadano un poco insensato que no tiene justificación más seria que la del afán de aventura para irse al norte. Además de señalar el carácter clandestino del éxodo, ${ }^{68}$ la imagen del bracero que, proyectada por periódicos regionales como El Sol de León, pone énfasis en la "irresponsabilidad" del trabajador migrante al mismo tiempo que lo acusa de improductividad:

La sed de aventura más que el amor a los dólares ha hecho que centenares de leoneses abandonen sus actividades para ir en busca de una tarjeta para enrolarse como braceros ocasionando con ello según se afirma, que anto [sic] las obras que llevan a cabo el Ayuntamiento y empresas particulares no se aceleren a su máximo sino que por el contrario se interrumpan considerablemente.

Como caso concreto se citan los trabajos de empedrado, pavimentación, etcétera, que realiza la Presidencia Municipal en distintos rumbos de la población, las cuales se han visto interrumpidas parcialmente por la falta de personal, ya que muchos de los trabajadores han solicitado permiso temporal o han renunciado para irse a trabajar a los talleres y campos agrícolas de la Unión Americana. ${ }^{69}$

En enero de 1954, en un artículo titulado "Ofensa a la dignidad mexicana”, el senador campechano Alberto Trueba Urbina reporta cómo la salida de los braceros "representa una sangría y un daño en lo económico que se puede calcular en muchos millones de pesos que pierde la economía nacional por la ausencia de esos brazos en las tareas de producción que el país requiere". ${ }^{70}$ Esta opinión es transmitida también en las páginas del diario de León; el editorialista considera la "sangría de campesinos" como algo terrible que perjudica el "esfuerzo de la producción" y como una "grave mutilación demográfica cuyas consecuencias redundan en el crecimiento verdadero del país". ${ }^{71}$ Este discurso que presenta al bracero (que vaya legal o ilegalmente a Estados Unidos) como perjudicial a los esfuerzos productivos nacionales se relaciona también con la situación que se vive en algunas regiones más dinámicas de la república, principalmente en los estados

68 "Pocos braceros han sido contratados legalmente", El Sol de León, 15 de mayo de 1953, p. 1.

69 "Los braceros tienen la culpa de que no terminen las obras", El Sol de León, 15 de mayo de 1953, p. 1.

70 "Ofensa a la dignidad de la nación mexicana”, El Popular, 15 de enero de 1954, p. 1 y 2.

71 “Sigue la sangría de campesinos”, El Sol de León, 15 de mayo de 1953, p. 4. 
norteños del país en los cuales la producción comercial del algodón está en crecimiento. La competencia de los salarios estadounidenses está en aquel entonces considerada como desleal; por lo tanto, los trabajadores mexicanos que cruzan al otro lado participan en el problema de escasez de mano de obra en regiones como Empalme (donde se encuentra un centro de reclutamiento de braceros). Rosario Robles reporta que en 1953 se crea la Bolsa Nacional de Trabajo para evitar precisamente la salida masiva de los trabajadores mexicanos y canalizarlos al interior del país, sin mucho éxito. ${ }^{72}$

Por otra parte, en estos tiempos de austeridad, todo gasto que debe realizar el gobierno es visto como extremadamente significativo y se calcula entonces que los gastos innecesarios deben verse ahorrados. Esta lógica discursiva se inscribe en la campaña de moralidad pública y de austeridad del presidente Ruiz Cortines. Además de acusar a los braceros (es importante señalar que los periódicos no siempre hacen una diferenciación entre braceros legalmente contratados y los "mojados", o cualquier otro tipo de migrante clandestino) de traicionar a la patria al irse por el "señuelo del dólar", denuncian los costos que corren a cuenta del gobierno mexicano por su deportación. Aunque el transporte del interior de los Estados Unidos hacia la frontera mexicano-americana corre a cuenta del gobierno estadounidense, la Secretaría de Gobernación de México debe prever cierto presupuesto para ofrecer transporte y comida a los centenares, a veces miles, de personas que se quedan atrapadas en las ciudades fronterizas. En marzo de 1953, empiezan a aparecer varias noticias sobre la intensificación de las deportaciones que, por cierto, van aumentando durante el verano; algunas de estas notas periodísticas rinden cuenta de los gastos incurridos: "Más de cinco millones de pesos se gastan anualmente los gobiernos de los Estados y el Gobierno Federal para movilizar a los millares de campesinos que son deportados por las autoridades americanas de Migración”. ${ }^{73}$

Cuando el ritmo de las deportaciones se acelera, simultáneamente a la reanudación de las negociaciones entre México y Estados Unidos, las opiniones en los periódicos son encontradas. Mientras que en unos titulares

${ }^{72}$ Rosario Robles B., “Migraciones rurales y jornaleros agrícolas, 1950-1970”, en Julio Moguel (coord.), Historia de la cuestión agraria mexicana. La época de oro y el principio de la crisis de la agricultura mexicana, 1950-1970, México, Centro de Estudios Históricos sobre el Agrarismo en México/Siglo XXI, 1988, t. 7, p. 125.

73 "Lo que cuestan al Gobierno los deportados de EEUU", El Popular, 2 de marzo de 1953, p. 1 y 4 . 
se denuncia el trato expeditivo, por no decir irrespetuoso, a los deportados (tanto por parte del Immigration and Naturalization Service que de las autoridades mexicanas), otros artículos señalan el carácter indigente de dichos sujetos y la molestia que representan para varias ciudades. Aguascalientes es una de estas municipalidades que reciben gran número de deportados por su red ferrocarrilera y de transportes. En la tercera semana de septiembre de 1953, aparecen notas relacionadas con esta situación. Por un lado, una noticia informa que los "pordioseros y vagos" que se quedan en los andenes de la estación del ferrocarril serán desalojados a partir del 1o. de octubre, y esto, con el objetivo de que "los visitantes no reciban desagradable impresión de la ciudad al llegar a ella". ${ }^{74}$ Sin nombrarlos, es claro que hacen referencia a los braceros y a los mojados deportados; la caricatura publicada el día anterior confirma que Aguascalientes está preocupada por la presencia de los deportados (véase la figura 2).

En esta imagen, se aprecia el título del periódico que refiere a la presencia masiva de braceros (tanto de los candidatos decepcionados como de los deportados). Abajo, la discusión entre los dos hombres de clase media alta señala la poca consideración que tiene por el devenir de estos migrantes:

-Por lo menos no se resfrían.

- iClaro! Espaldas mojadas en Aguascalientes. ${ }^{75}$

Esta tendencia a ver al bracero como un sujeto antipatriótico favorece la instauración de un programa de trabajo nacional, visto entonces como el requisito nacional para poder participar en el programa bracero. Hacia principios de la década de 1950, con base en las denuncias por parte de agricultores de estados fronterizos como Chihuahua en contra de la salida de braceros ${ }^{76}$ las autoridades empiezan a considerar la redirección de los braceros a los campos algodoneros (que experimentan su auge precisamente durante esa década y la siguiente) de los estados fronterizos mexicanos. En 1954, las peticiones de los dirigentes campesinos para un programa sistemático de abastecimiento de mano de obra agrícola se vuelven recurrentes y proponen al bracero como la solución: "dirigentes campesinos [...] están concentrando los informes de sus delegados en el interior del

\footnotetext{
74 “Retirarán a vagos y pordioseros”, Excélsior, 23 de septiembre de 1953, p. 4-A.

75 "Retirarán a vagos y pordioseros”, Excélsior, 23 de septiembre de 1953, p. 4-A.

76 "Chihuahua, contra la salida de braceros”, Excélsior, 3 de octubre de 1953, p. A-1.
} 


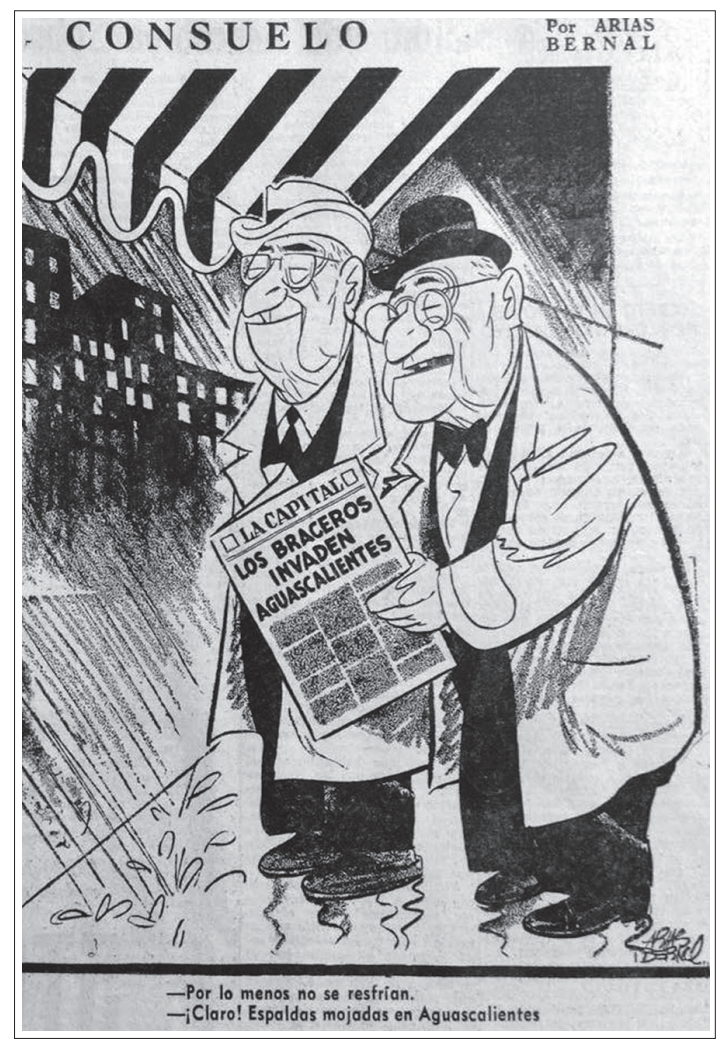

Figura 2. Arias Bernal, “Consuelo”, Excélsior, 22 de septiembre de 1953

país, para solicitar del Gobierno que se asegure la administración de mano de obra para las labores agrícolas, prohibiendo la salida de braceros". ${ }^{77}$ En 1956, el gobierno mexicano parece dar su visto bueno a este tipo de "programa bracero" nacional. ${ }^{78}$

Enajenar al bracero parece entonces inscribirse en una lógica de despersonalización que permite recuperar esta figura para hacerlo responsable de ciertos males, y así exonerar al gobierno mexicano por la gestión problemática de situaciones económicas adversas. La animadversión frente al bracero, o al trabajador irregular, aparece claramente en las notas periodísticas que tienden a echar la culpa de la carestía de la vida a este sujeto marginal.

77 “Alarmante escasez de peones en los campos", El Popular, 13 de enero de 1954.

${ }^{78}$ Sergio Chávez, "The Sonoran Desert's Domestic Bracero Programme: Institutional Actors and the Creation of Labour Migration Streams", International Migration, v. 50, n. 2, 2012, p. 20-40. 
Su marginalidad no solamente se limita al suelo mexicano, también el trato que se le da por parte de los cónsules en Estados Unidos es una señal del desprecio con el cual está considerado durante este año de $1953 .^{79}$

\section{Conclusiones}

Las adversidades económicas que sufre el pueblo ocasionan reacciones diversas y provocan un descontento muy propicio para el florecimiento de ideas y discursos excluyentes y hostiles. La carestía de la vida en aquellos meses de 1953, y la voluntad del gobierno ruizcortinista de restablecer una propuesta nacionalista moralizadora propició la reaparición de ciertas características xenófobas de la sociedad mexicana que se manifestaron al momento de buscar algunos chivos expiatorios.

Esta campaña de moralidad pública forma parte de la estrategia ruizcortinista para alejarse de la facción gobernante anterior, al promover la lucha contra ciertos elementos antipatrióticos de la sociedad. Particularmente, en este artículo se ha visto cómo las percepciones que se tiene de los panaderos españoles y de los braceros en la prensa mexicana son instrumentalizadas en un momento particularmente interesante: el año de 1953, caracterizado por una recesión significativa y una búsqueda de legitimidad política. Estos meses son relevantes porque se presenta entonces una crisis del poder de compra, y del abastecimiento, en la ciudad de México; durante este difícil año, la idea del español acaparador y la del bracero traidor son instrumentalizadas para reforzar la idea de la rectitud del gobierno ruizcortinista y de su afán por combatir el encarecimiento. Por otra parte, estos meses son también centrales para el programa de trabajo temporal bilateral entre Estados Unidos y México, lo cual explica en parte la proyección negativa del bracero en la prensa.

Los diarios capitalinos permiten entrever una apreciación de los panaderos que se nutre de los estereotipos históricos respecto de la comunidad española en México. Durante estos meses inflacionarios y de escasez de productos, al discurso nacionalista y moralista del presidente Ruiz Cortines se agregan estrategias de supervisión de los extranjeros en el país. En general, los cambios que el gobierno desea aportar al Registro Nacional de

79 "Indiferencia de los cónsules mexicanos hacia los braceros", Excélsior, 3 de junio de 1953, p. 4-A. 
Extranjeros tienen como objetivo vigilar más de cerca a estos residentes. En particular, se da a entender que los indeseables son sobre todo los que no contribuyen de manera positiva a la sociedad. Entre ellos, están los panaderos españoles, considerados (históricamente) como unos monopolistas sinvergüenzas; por otro lado, se cuestionó la lealtad de los braceros -estos nuevos sujetos transnacionales que ya no eran completamente mexicanos ni tampoco agringados- por abandonar al campo mexicano en beneficio de la agricultura estadounidense.

Los panaderos españoles monopolistas fueron vistos como participantes de la carestía de la vida, en contraposición al actuar patriótico deseado. Por su participación en maniobras monopolísticas, algo ampliamente denunciado por el gobierno ruizcortinista, estos extranjeros fueron vistos como irrespetuosos de las políticas nacionales y del pueblo mexicano. Durante el periodo de inflación que se vivió a principios de 1953, aumentar el costo del pan, elemento central en las mesas capitalinas, la prensa se nutrió de los estereotipos históricos alrededor del panadero español.

Este contexto de austeridad y de moralidad patriótica fomentó también la aparición de una retórica que tendía a echar la culpa de los elevados precios y la escasez de alimentos a los trabajadores migrantes, legales o ilegales. Esto ocurre en un momento en el cual las negociaciones entre Estados Unidos y México se vuelven tensas y que el gobierno mexicano quiere evitar la salida de los jornaleros. Algunas notas periodísticas parecen formar parte de una estrategia para desincentivarlos a irse para el norte. Al retratar al bracero como un sujeto antipatriótico que abandona sus labores productivas en México, quizá se esperaba que los otros candidatos a la migración no emprendieran el viaje a Estados Unidos. Sin embargo, esta campaña tuvo como resultado poner en cuestión a la lealtad y el patriotismo del bracero, presentarlo como uno de los culpables de la situación económica deplorable que caracterizó al año 1953.

Este trabajo demostró cómo estos discursos (re)aparecen bajo ciertas circunstancias y cómo estos estereotipos están estrechamente conectados con los acontecimientos socioeconómicos y políticos que se viven en México. El lema del nuevo presidente "Austeridad y trabajo" y la aplicación de los preceptos propuestos durante la campaña electoral para sanear al gobierno y a la nación mexicana ciertamente influyeron en la estrategia discursiva relacionada con los extranjeros y los emigrantes.

El caso de México en el año de 1953 no es único. Las cacerías de brujas y la búsqueda de un chivo expiatorio suelen acompañar las crisis de 
distintas índoles. En varias ocasiones, la mirada del pueblo y de sus gobernantes se dirigirá hacia los elementos foráneos al cuerpo nacional; los migrantes serán entonces vistos como una amenaza a la estabilidad económica (y política), al robar los empleos o las oportunidades de los nacionales. Simultáneamente, los grupos sociales más afectados por los problemas económicos, así como los líderes políticos interesados en estas clientelas electorales, encontrarán otros culpables nacionales, lo que reforzará la idea de que los valientes trabajadores, y sus gobiernos, han creado la situación problemática a la cual están confrontados. En todos estos casos, los culposos no son considerados como formando completamente parte del cuerpo nacional. Los migrantes por abandonar su patria y por ser "duales". Los extranjeros por no haber nacido en el país y ser los otros. Su lealtad y su patriotismo serán más fácilmente discutidos. En el caso de los "malhechores" nacionales, su pertenencia a la nación es también debatida. En la situación de 1953, la sociedad encontró a estos culpables, no plenamente mexicanos, en la figura de los españoles monopolistas y de los trabajadores migrantes.

\section{BiBLIOGRAFÍA}

"El pan en el tiempo", Karsapan, https://karsapan.com.mx/el-pan-en-el-tiempo/ (consultado el 28 de junio de 2019).

"Nuestra empresa, PanRoll, http://www.panroll.com.mx/nuestra-empresa (consultado el 1 de julio de 2019).

Aguilar Rodríguez, Sandra, "La mesa está servida: comida y vida cotidiana en el México de mediados del siglo xx", Revista de Historia Iberoamericana, v. 2, n. 2, 2009, p. 52-85.

Burkholder de la Rosa, Arno, La red de los espejos. Una historia del diario Excélsior, 1916-1976, México, Fondo de Cultura Económica, 2016.

Cárdenas, Enrique, La política económica en México, 1950-1994, México, Fondo de Cultura Económica, 2012.

ChÁvez, Sergio, "The Sonoran Desert's Domestic Bracero Programme: Institutional Actors and the Creation of Labour Migration Streams", International Migration, v. 50, n. 2, 2012, p. 20-40.

Cedillo, Juan Alberto, La cosa nostra en México (1938-1950). Los negocios de Lucky Luciano y la mujer que corrompió al gobierno mexicano, México, Grijalbo, 2011. 
Craig, Richard B., The Bracero Program: Interest Groups and Foreign Policy, Austin, University of Texas Press, 1971.

DurAnd, Jorge, Braceros. Las miradas mexicana y estadounidense. Antología (19451964), México, Senado de la República/Universidad Autónoma de Zacatecas/ Miguel Ángel Porrúa, 2007.

Gil LÁzARo, Alicia, “¿Hidalgo o gachupín? Imágenes en torno al inmigrante español en el México revolucionario”, en Agustín Sánchez Andrés, Tomás Pérez Vejo y Marco Antonio Landavazo (coords.), Imágenes e imaginarios sobre España en México, siglos XIX y XX, México, Porrúa/Universidad Michoacana de San Nicolás de Hidalgo/Consejo Nacional de Ciencia y Tecnología, 2007, p. 367-399.

"La presencia de españoles en México en el siglo xx. Continuidades y rupturas en una visión panorámica desde el final del Porfiriato hasta los años ochenta, 1910-1980”, en Ernesto Rodríguez Chávez (coord.), Extranjeros en México. Continuidades y aproximaciones, México, Instituto Nacional de Migración/DGE Ediciones, 2010, p. 133-172.

"De colonizadores a inmigrantes gachupines. Los discursos sobre los españoles en la esfera pública mexicana (1880-1930)”, Revista Latino-Americana de História, v. 6, n. 17, 2017, p. 115-134.

GonzÁlez Navarro, Moisés, Los extranjeros en México y los mexicanos en el extranjero, 1821-1970, México, El Colegio de México, 1994, v. III.

"Xenofobia y xenofilia en la Revolución Mexicana", Historia Mexicana, v. 18 , n. 4 , 1969, p. 569-614.

KraUze, Enrique, La presidencia imperial. De Manuel Ávila Camacho a Carlos Salinas de Gortari, México, Tusquets Editores, 1997.

Mexico: Biography of Power. A History of Modern Mexico, 1810-1996, New York, HarperCollins, 1997.

LIDA, Clara E., “Los españoles en el México independiente: 1821-1950. Un estado de la cuestión”, Historia Mexicana, v. 56, n. 2, 2006, p. 613-650.

Luna Elizarrarás, Sara Minerva, "Enriquecimiento y legitimidad presidencial. Discusión sobre identidades masculinas durante la campaña moralizadora de Adolfo Ruiz Cortines”, Historia Mexicana, v. 63, n. 3, 2014, p. 1377-1420.

Moreno-Brid, Juan Carlos, y Jaime Ros Bosch, Desarrollo y crecimiento en la economía mexicana. Una perspectiva histórica, México, Fondo de Cultura Económica, 2009.

PARdo, María del Carmen, La modernización administrativa en México. Propuesta para explicar los cambios en la estructura pública, 1940-1990, México, Instituto Nacional de Administración Pública/El Colegio de México, 1991. 
Pellicer de Brody, Olga, y Esteban L. Mancilla, El entendimiento con los Estados Unidos y la gestación del desarrollo estabilizador, México, El Colegio de México, 1978.

Pellicer de Brody, Olga, y José Luis Reyna, Historia de la Revolución Mexicana, 1952-1960. El afianzamiento de la estabilidad política, México, El Colegio de México, 2002.

Pérez Vejo, Tomás, "La difícil herencia: hispanofobia e hispanofilia en el proceso de construcción nacional mexicano”, en Manuel Suárez Cortina y Tomás Pérez Vejo (coords.), Los caminos de la ciudadanía: México y España en perspectiva comparada, Madrid, Biblioteca Nueva/Universidad de Cantabria, PUbli-Can-Ediciones, 2010, p. 219-230.

Pla Brugat, Dolores, "Ser español en México, para bien y para mal”, en Delia Salazar Anaya, Xenofobia y xenofilia en la historia de México, siglos XIX y XX, México, Instituto Nacional de Migración/Instituto Nacional de Antropología e Historia/DGE Ediciones, 2006, p. 135-158.

Reyna, José Luis, y Raúl Trejo Delarbre, La clase obrera en la historia de México. De Adolfo Ruiz Cortines a Adolfo López Mateos (1952-1964), México, Siglo XXI/ Universidad Nacional Autónoma de México, Instituto de Investigaciones Sociales, 1996.

Robles B., Rosario, “Migraciones rurales y jornaleros agrícolas, 1950-1970”, en Julio Moguel (coord.), Historia de la cuestión agraria mexicana. La época de oro y el principio de la crisis de la agricultura mexicana, 1950-1970, México, Centro de Estudios Históricos sobre el Agrarismo en México/Siglo XXI, 1988, t. 7, p. 113-145.

Rodríguez Kuri, Ariel, “Los años maravillosos”, en Will Fowler (coord.), Los gobernantes mexicanos, México, Fondo de Cultura Económica, 2008, t. II, p. 263-287.

“Desabasto, hambre y respuesta política, 1915”, en Carlos Illades y Ariel Rodríguez Kuri (coords.), Instituciones y ciudad. Ocho estudios históricos sobre la ciudad de México, México, ¡Uníos!, 2000.

SeCretaría de Industria y Comercio, Dirección General de Estadística, "Población extranjera residente, por entidad federativa de residencia y país de nacimiento, según sexo”, Octavo Censo General de Población, México, Secretaría de Industria y Comercio, Dirección General de Estadística, 1960, https://www. inegi.org.mx/programas/ccpv/1960/default.html\#Tabulados (consultado el 5 de agosto de 2017).

, "Población total, por entidad federativa de residencia, sexo y censo, según lugar de nacimiento”, en Octavo Censo General de Población, México, Secretaría de Industria y Comercio, Dirección General de Estadística, 1960, https://www. 
inegi.org.mx/programas/ccpv/1960/default.html\#Tabulados (consultado el 5 de agosto de 2017).

Serna Rodríguez, Ana María, "Prensa y sociedad en las décadas revolucionarias (1910-1940)", Secuencia, n. 26, 2014, p. 109-149.

Servín, Elisa, "El movimiento henriquista y la reivindicación de la Revolución Mexicana", Desacatos, n. 1, 1999.

Smith, Benjamin T., The Mexican Press and Civil Society, 1940-1976, Chapel Hill, University of North Carolina Press, 2018.

VÉzina, Catherine, Diplomacia migratoria: una historia transnacional del Programa Bracero, 1947-1952, México, Secretaría de Relaciones Exteriores/Centro de Investigación y Docencia Económicas, 2017.

"El bracero, ¿héroe o paria? Su representación mediática, 1942-1964", Signos Históricos, v. XXI, n. 42, julio-diciembre de 2018, p. 180-221.

Weis, Robert, "Las panaderías en la ciudad de México de Porfirio Díaz: los empresarios vasco-navarros y la movilización obrera”, Revista de Estudios Sociales, n. 29,2008 , p. $70-85$.

, "Immigrant Entrepreneurs, Bread, and Class Negotiation in Postrevolutionary Mexico City", Mexican Studies, v. 25, n. 1, 2009, p. 71-100.

Bakers and Basques: A Social History of Bread in Mexico, Albuquerque, University of New Mexico Press, 2012.

Yankelevich, Pablo, "La política de expulsión de españoles indeseables en México (1915-1934)”, Revista de Indias, v. 63, n. 228, 2003, p. 495-518.

"Hispanofobia y revolución: españoles expulsados de México (19111940)", Hispanic American Historical Review, v. 86, n. 1, 2006, p. 29-60.

"Denuncias e investigaciones contra españoles. Orígenes y desenvolvimiento de una conducta social y una práctica política en el México revolucionario", en Agustín Sánchez Andrés, Tomás Pérez Vejo y Marco Antonio Landavazo (coords.), Imágenes e imaginarios sobre España en México, siglos XIX y Xx, México, Porrúa/Universidad Michoacana de San Nicolás de Hidalgo/ Consejo Nacional de Ciencia y Tecnología, 2007, p. 425-463. 